\title{
Correction to: Use of a NAT-based assay to improve the surveillance system and prevent transfusion-transmitted malaria in blood banks
}

\author{
Daniele Rocha ${ }^{3,5}$, Gisely Cardoso de Melo ${ }^{1,2}$, José Marcelo Hipólito Carneiro ${ }^{6}$, Marisa Ribeiro ${ }^{3,5}$, \\ Sthefanie Ribeiro ${ }^{3}$, Daniela Tupy de Godoy ${ }^{3}$, Elaine Costa ${ }^{3}$, Anne Cristine Gomes de Almeida ${ }^{1}$, \\ Elisabete Ferreira de Andrade ${ }^{3,5}$, Cláudia Maria de Moura Abrahim ${ }^{6}$, Nelson Abrahim Fraiji ${ }^{6}$, \\ Antonio Gomes Pinto Ferreira ${ }^{3}$, Wuelton Marcelo Monteiro ${ }^{1,2}$, Rodrigo Brindeiro ${ }^{5}$, Amilcar Tanuri ${ }^{5}$, \\ Marcus Vinicius Guimarães de Lacerda ${ }^{1,2,4}$ and Patrícia Alvarez ${ }^{3 *}$ (1)
}

\section{Correction to: Malar J (2020) 19:275 https://doi.org/10.1186/s12936-020-03345 $-y$}

Following publication of the original article [1], the authors flagged that an author has been erroneously excluded from the article's authorship.

The missing author is Elaine Costa, who was part of the team that validated the NAT platform, did the pilot study and analyzed the results.

To correct this error, please find Elaine Costa included in the author list of this correction.

In addition, please see here for the (corrected) Author Contributions statement:

GCM, ACGA, JHC, CMMA, NAF were responsible for patient recruitment and laboratory procedures; DR, MR, SR,EC, EFA validated the NAT platform and did the pilot study; DR, GCM, DTG, AT analyzed the results and wrote first draft of the manuscript; PA, GCM, AGPF, AT, WMM, and MVGL analyzed the results, revised and approved the final version of the manuscript.

The authors apologize for any inconvenience caused.

The original article can be found online at https://doi.org/10.1186/s1293 6-020-03345-y

${ }^{*}$ Correspondence: palvarez@bio.focruz.br

${ }^{3}$ Institute of Technology in Immunobiology Bio-Manguinhos, Oswaldo Cruz Foundation/Fiocruz, Avenida Brasil 4365, Rio de Janeiro, Brazil

Full list of author information is available at the end of the article

\begin{abstract}
Author details
${ }^{1}$ Instituto de Pesquisa Clínica Carlos Borborema, Fundação de Medicina Tropical Heitor Vieira Dourado, Manaus, Amazonas, Brazil. ${ }^{2}$ Universidade do Estado do Amazonas, Manaus, Amazonas, Brazil. ${ }^{3}$ Institute of Technology in Immunobiology Bio-Manguinhos, Oswaldo Cruz Foundation/Fiocruz, Avenida Brasil 4365, Rio de Janeiro, Brazil. ${ }^{4}$ Instituto de Pesquisas Leônidas e Maria Deane, Fiocruz, Manaus, Amazonas, Brazil. ${ }^{5}$ Departamento de Genética, Universidade Federal do Rio de Janeiro-UFRJ, Rio de Janeiro, Brazil. ${ }^{6}$ HEMOAMFundação Hospitalar de Hematologia e Hemoterapia do Amazonas, Manaus, Amazonas, Brazil.
\end{abstract}

Published online: 04 September 2020

\section{Reference}

1. Rocha D, de Melo GC, Carneiro JMH, Ribeiro M, Ribeiro S, de Godoy DT, Costa E, de Almeida ACG, de Andrade EF, de Moura Abrahim CM, Fraiji NA, Ferreira AGP, Monteiro WM, Brindeiro R, Tanuri A, de Lacerda MVG, Alvarez P. Use of a NAT-based assay to improve the surveillance system and prevent transfusion-transmitted malaria in blood banks. Malar J. 2020;19:275. https://doi.org/10.1186/s12936-020-03345-y.

\section{Publisher's Note}

Springer Nature remains neutral with regard to jurisdictional claims in published maps and institutional affiliations.

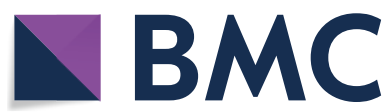

(O) The Author(s) 2020. This article is licensed under a Creative Commons Attribution 4.0 International License, which permits use, sharing, adaptation, distribution and reproduction in any medium or format, as long as you give appropriate credit to the original author(s) and the source, provide a link to the Creative Commons licence, and indicate if changes were made. The images or other third party material in this article are included in the article's Creative Commons licence, unless indicated otherwise in a credit line to the material. If material is not included in the article's Creative Commons licence and your intended use is not permitted by statutory regulation or exceeds the permitted use, you will need to obtain permission directly from the copyright holder. To view a copy of this licence, visit http://creativeco mmons.org/licenses/by/4.0/. The Creative Commons Public Domain Dedication waiver (http://creativecommons.org/publicdomain/ zero/1.0/) applies to the data made available in this article, unless otherwise stated in a credit line to the data. 